Article

\title{
Synthesis of $\mathrm{SiC} / \mathrm{Ag} / \mathrm{Cellulose}$ Nanocomposite and Its Antibacterial Activity by Reactive Oxygen Species Generation
}

\author{
Andrzej Borkowski ${ }^{1}{ }^{*}$, Tomasz Cłapa ${ }^{2}$, Mateusz Szala ${ }^{3}$, Arkadiusz Gąsiński ${ }^{1}$ and \\ Marek Selwet ${ }^{2}$ \\ 1 Faculty of Geology, University of Warsaw, Żwirki i Wigury 93, 02-089 Warsaw, Poland; agasin@uw.edu.pl \\ 2 Department of General and Environmental Microbiology, Poznań University of Life Sciences, \\ ul. Szydłowska 50, 60-656 Poznań, Poland; tom.clapa@gmail.com (T.C.); marek.selwet@gmail.com (M.S.) \\ 3 Faculty of Advanced Technologies and Chemistry, Military University of Technology, Kaliskiego 2, \\ 00-908 Warsaw, Poland; mateusz.szala@wat.edu.pl \\ * Correspondence: a.borkowski@uw.edu.pl; Tel.: +48-22-55-40-321 \\ Academic Editor: Guogang Ren \\ Received: 13 June 2016; Accepted: 18 August 2016; Published: 13 September 2016
}

\begin{abstract}
We describe the synthesis of nanocomposites, based on nanofibers of silicon carbide, silver nanoparticles, and cellulose. Silver nanoparticle synthesis was achieved with chemical reduction using hydrazine by adding two different surfactants to obtain a nanocomposite with silver nanoparticles of different diameters. Determination of antibacterial activity was based on respiration tests. Enzymatic analysis indicates oxidative stress, and viability testing was conducted using an epifluorescence microscope. Strong bactericidal activity of nanocomposites was found against bacteria Escherichia coli and Bacillus cereus, which were used in the study as typical Gram-negative and Gram-positive bacteria, respectively. It is assumed that reactive oxygen species generation was responsible for the observed antibacterial effect of the investigated materials. Due to the properties of silicon carbide nanofiber, the obtained nanocomposite may have potential use in technology related to water and air purification. Cellulose addition prevented silver nanoparticle release and probably enhanced bacterial adsorption onto aggregates of the nanocomposite material.
\end{abstract}

Keywords: Ag nanoparticles; antibacterial activity; cellulose; reactive oxygen species; silicon carbide nanocomposite

\section{Introduction}

Following a period of intensive fundamental research on nanostructured materials, their possible use in a variety of technologies is a new direction of research. Opportunities exist in the application of nanostructured materials in medicine, exploring bactericidal and cytotoxic properties, and in technologies related to biotechnology and the chemical industry. An important potential area of application of nanostructured materials is in water- and air-treatment technologies. For this reason, many studies have been published, where the possibility of synthesis of a wide variety of nanocomposites, based primarily on single- and multi-walled carbon nanotubes, and graphene, combined with metal and metal oxide nanoparticles, have been presented [1-4]. The most interesting studies related to nanocomposites include those where silver, zinc oxide, and titanium oxide nanoparticles were used. Very often, nanostructured carbon is treated as a nanoparticle carrier. One such carrier is silicon carbide ( $\mathrm{SiC})$ nanofibers, which are chemically more stable than nanostructured carbon, and, therefore, have potential application in technologies based on filtering methods.

$\mathrm{SiC}$ nanostructures are comprised mainly of $\mathrm{SiC}$ nanofibers and nanorods, which may be obtained using combustion synthesis $[5,6]$. In this method, after product purification, a material can be 
produced that consists almost exclusively of nanostructured SiC. Nanofibers, nanorods, and $\mathrm{SiC}$ nanoparticles can exhibit antibacterial properties by injury of cell membrane integrity and generation of oxidative stress [7-10]. Such a bactericidal mechanism has been observed with various nanostructured materials [11,12]. Of particular interest are metal nanoparticles, mainly silver nanoparticles (AgNPs), which have strong bactericidal properties [13-18]. The main mechanisms of the bactericidal action of AgNPs are: (1) interaction of AgNPs with the bacterial membranes; (2) the generation of reactive oxygen species (ROS), which may lead to a number of adverse processes in cells, such as changes in enzyme activity, lipid peroxidation, growth inhibition, and cell death; and (3) release of toxic Ag ions. It is possible that the release of $\mathrm{Ag}$ ions is the most important factor leading to cell injury due to contact with AgNPs. Kittler et al. [19] concluded that the toxicity of AgNPs increased during storage due to the dissociation of Ag ions.

The use of AgNPs and other metal and metal oxide nanoparticles may be limited to the synthesis of a suspension in a suitable liquid or semi-liquid medium, where the suspension should have the desired properties that limit microbial growth. For solids, such an approach may be more cumbersome; therefore, a variety of nanocomposite materials containing metal nanoparticles may be required. For instance, the bactericidal activity of nanocomposites based on graphene oxide/chitosan/ZnO nanoparticles has been demonstrated [4]. The most common AgNPs or metal nanoparticles synthesis method is chemical reduction under different conditions using, for example, monosaccharides [14] or hydrazine [20]. The addition of surfactants during the reduction allows for control of nanoparticle size and aggregate formation.

Cellulose has often been used as a material for nanocomposites with silver. It can be concluded that cellulose-based nanocomposites could be implemented as a promising antibacterial material, especially for food packaging and transport [21,22]. Dallas et al. [23] have reported that the cellulose-based nanocomposites and their derivatives are gaining importance because of their implementation in science and technology. They pay attention to possible applications, such as high-performance composite materials, organoclay-exfoliated cellulose with improved mechanical properties, or nanocomposites for biomedical applications. An interesting application of cellulose-based nanocomposites is the production of bacterial cellulose impregnated by AgNPs for use as a wound dressing [24].

The aim of this study was to use $\mathrm{SiC}$ nanofibers as a carrier for AgNPs. We present the synthesis of a nanocomposite material based on $\mathrm{SiC}$ nanofibers, AgNPs, and cellulose (CE). CE was added to stabilize the system and to prevent the release of AgNPs. The obtained nanocomposites were used in microbiological tests to determine their potential bactericidal properties. AgNPs were synthesized under two different surfactant addition conditions to obtain nanocomposites with various-sized AgNPs, and to evaluate the impact of the nanoparticles on the bactericidal activity of the nanocomposites.

\section{Results and Discussion}

\subsection{Nanocomposite Characterization}

The structures of the $\mathrm{SiC}$ nanofibers and nanocomposite $\mathrm{SiC} / \mathrm{CE}$ are presented in Figure 1. There were no significant microscopic differences between the $\mathrm{SiC}$ nanofibers and the $\mathrm{SiC} / \mathrm{CE}$ nanocomposite; only a portion of the fibers appeared to be joined closely together and were partially covered by CE. Based on weight analysis and the composition of the reagent used, the content of cellulose in the nanocomposite was about $7 \%-9 \%(w / w)$. The scanning electron microscopy (SEM) images of $\mathrm{SiC} / \mathrm{Ag} / \mathrm{CE} / \mathrm{SDS}$ (AgNPs synthesized via SDS-sodium dodecyl sulphate) and $\mathrm{SiC} / \mathrm{Ag} / \mathrm{CE} / \mathrm{T}$ nanocomposites (AgNPs synthesized via Tween) are shown in Figure 2. Micrographs were taken in backscattered electron mode to better visualize the silver nanoparticles. 


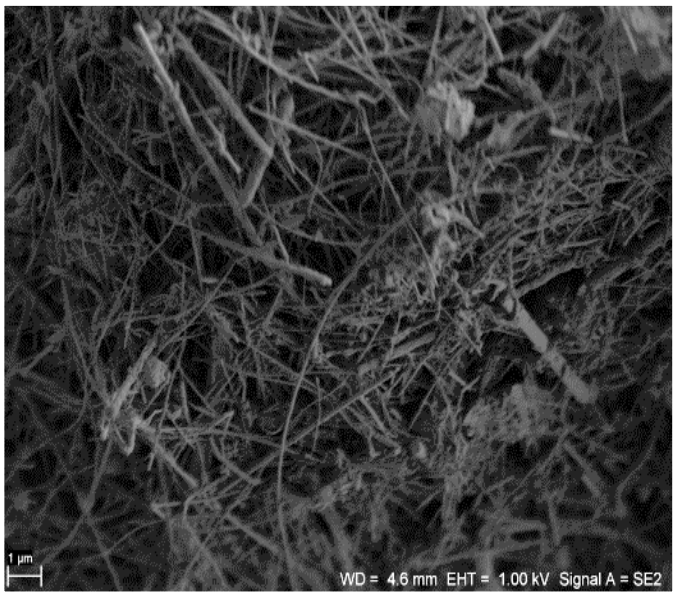

(a)

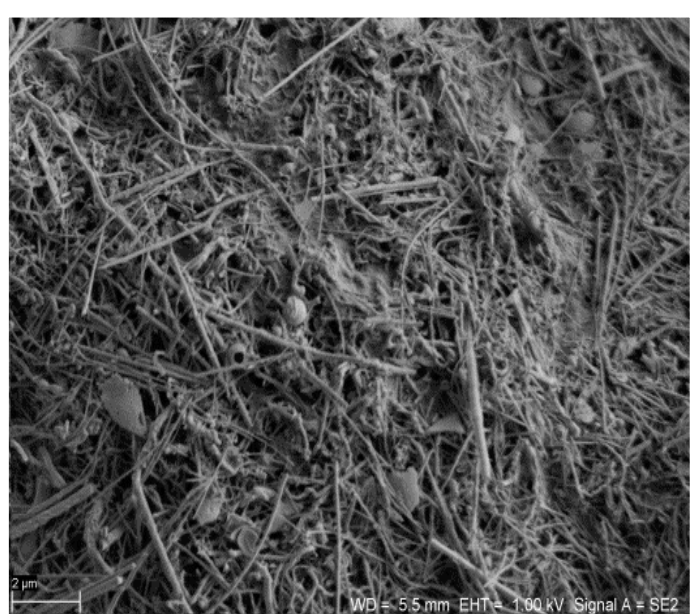

(b)

Figure 1. Scanning electron microscopy (SEM) images of (a) silicon carbide ( $\mathrm{SiC}$ ) nanofibers (Scale bar: $1 \mu \mathrm{m})$ and (b) the SiC/cellulose (CE) nanocomposite. (Scale bar: $2 \mu \mathrm{m}$ ).

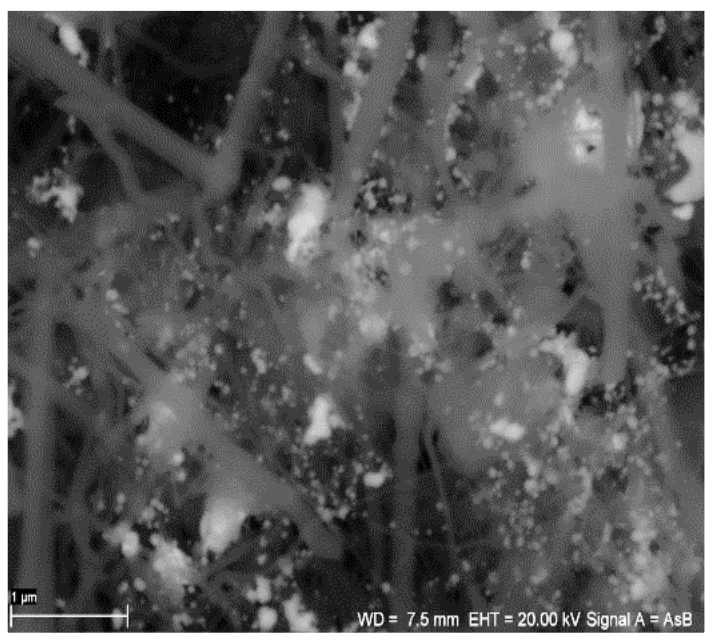

(a)

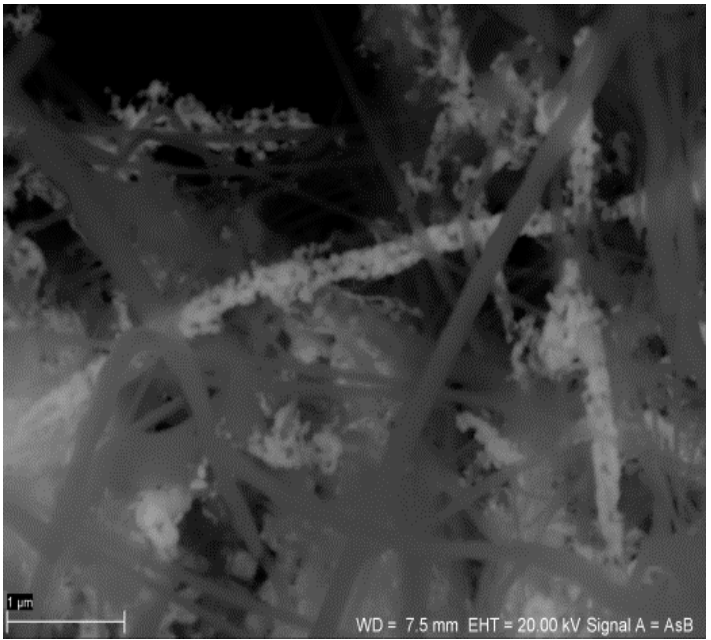

(b)

Figure 2. SEM images of (a) the $\mathrm{SiC} / \mathrm{Ag} / \mathrm{CE} / \mathrm{SDS}$ nanocomposite (AgNPs synthesized via SDS-sodium dodecyl sulphate) and (b) the $\mathrm{SiC} / \mathrm{Ag} / \mathrm{CE} / \mathrm{T}$ nanocomposite (AgNPs synthesized via Tween). (Scale bar: $1 \mu \mathrm{m})$.

AgNPs distribution was shown by energy-dispersive X-ray spectroscopy (Figure 3). For the first nanocomposite, AgNPs were more scattered, and for $\mathrm{SiC} / \mathrm{Ag} / \mathrm{CE} / \mathrm{T}, \mathrm{AgNPs}$ were associated strongly with the $\mathrm{SiC}$ nanofibers. It is possible that the linkage between the $\mathrm{SiC}$ nanofibers and AgNPs is a physical phenomenon rather than a chemical interaction. Therefore, it is also possible that AgNPs could be released from the nanocomposites. To minimize this effect, the obtained nanocomposite suspension was centrifuged and washed in deionized water until the unbound AgNPs were washed out. After such treatment, there was no peak at $390-420 \mathrm{~nm}$ in the filtrate. In preliminary experiments, it was found that CE prevented the release of AgNPs. Synthesis of the nanocomposite without the CE resulted in a more extensive release of AgNPs, which was observed as a peak at $390-420 \mathrm{~nm}$ after washing of the obtained nanocomposites. Thus, the addition of $\mathrm{CE}$ prevented the dispersion of non-associated AgNPs with $\mathrm{SiC}$ nanofibers in aqueous suspension. Furthermore, during the synthesis of $\mathrm{SiC} / \mathrm{Ag} / \mathrm{CE}$, the addition of $\mathrm{CE}$ resulted in the binding of remaining AgNPs. 


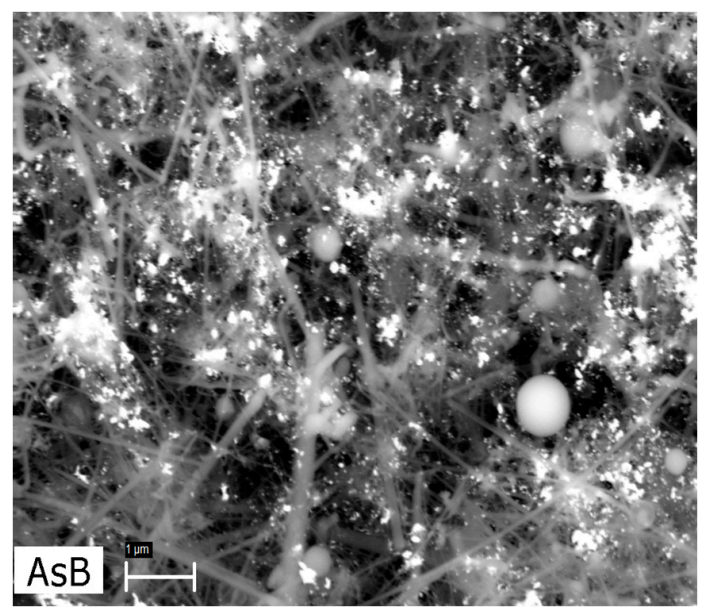

(a)

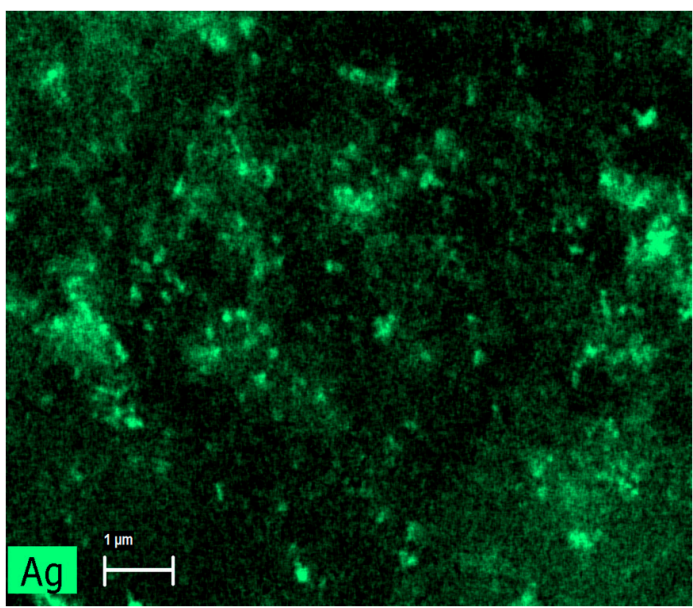

(b)

Figure 3. Example of energy-dispersive X-ray spectroscopy mapping. (a) SEM image in backscattered electron mode and (b) mapping indicating the distribution of $\mathrm{Ag}$ in the nanocomposite $\mathrm{SiC} / \mathrm{Ag} / \mathrm{CE} / \mathrm{SDS}$. AsB: backscattered electron mode. (Scale bar: $1 \mu \mathrm{m}$ ).

AgNPs synthesis was performed in 1\% SDS or Tween 20 solution. Surfactant addition mainly prevents the formation of the so-called silver mirror (Tollens reaction). SEM analysis of the obtained AgNPs revealed that the AgNP/SDS particle size ranged from 15 to $50 \mathrm{~nm}$, whereas for AgNP/T, particles formed aggregates larger than $200 \mathrm{~nm}$. These aggregates consisted of $\sim 10-\mathrm{nm}$ diameter nanoparticles (Figure 4). The difference between the obtained AgNPs was also visible in the ultraviolet-visible (UV-VIS) spectrum (Figure 5a).

Based on X-ray fluorescence spectrometry (XRF) analysis, it can be stated that the silver content in the nanocomposites was $2.88 \%$ and $2.33 \%$ for $\mathrm{SiC} / \mathrm{Ag} / \mathrm{CE} / \mathrm{SDS}$ and $\mathrm{SiC} / \mathrm{Ag} / \mathrm{CE} / \mathrm{T}$, respectively. The XRF spectrum (Figure $5 b$ ) revealed the presence of elements contained in the tested nanomaterial, namely $\mathrm{Ag}$ and $\mathrm{Si}$, and elements derived from various contaminants, such as Ca from substrates for combustion synthesis. The Fe signal was most likely derived from the device casing. These contaminants were comparable in the studied materials. X-ray powder diffraction (XRD) analysis (Figure 6) revealed characteristic peaks for $\mathrm{SiC}$ and $\mathrm{Ag}$ for $\mathrm{SiC} / \mathrm{Ag} / \mathrm{CE}$ nanocomposites. Calcium fluoride $\left(\mathrm{CaF}_{2}\right)$ was a contaminant from combustion synthesis.

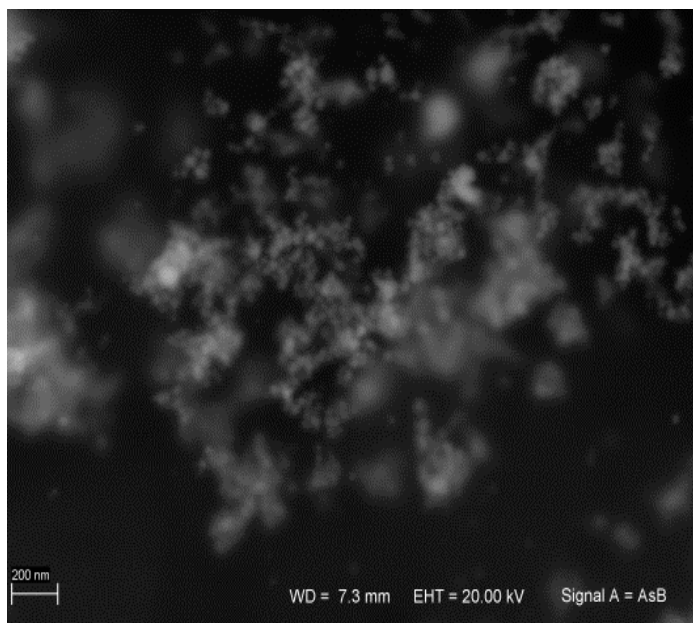

(a)

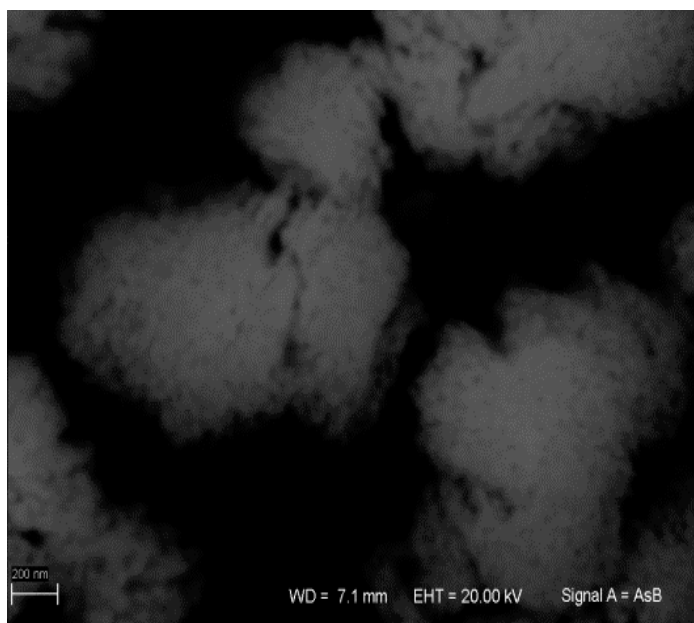

(b)

Figure 4. (a) Ag nanoparticles synthesized via SDS (AgNP/SDS); and (b) Ag nanoparticles synthesized via Tween 20 (AgNP/T). (Scale bar: $200 \mathrm{~nm}$ ). 


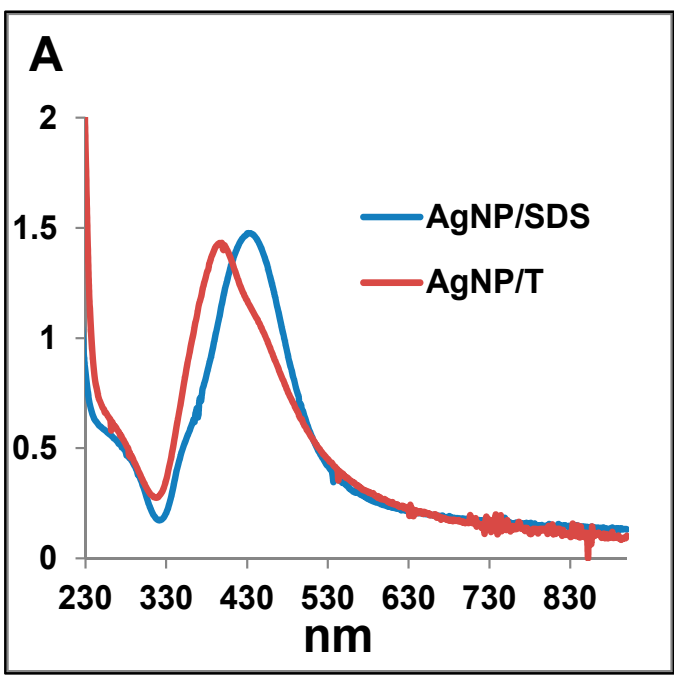

(a)

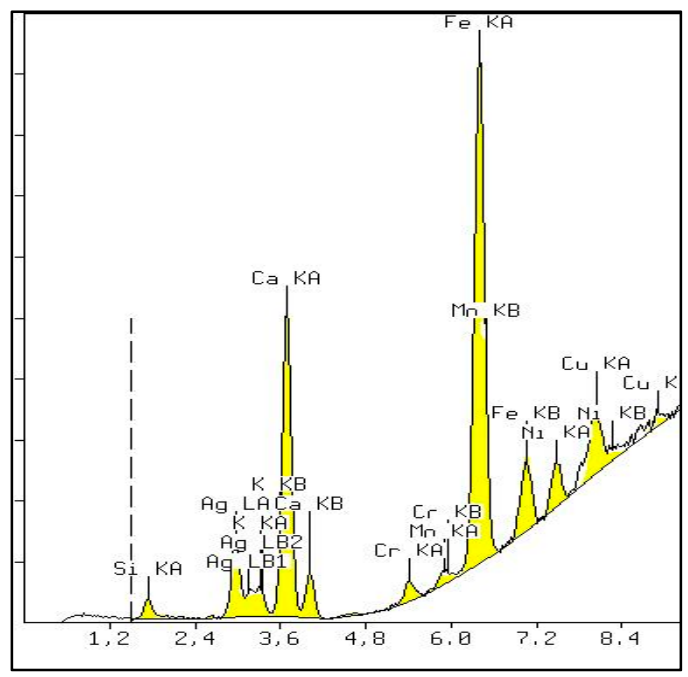

(b)

Figure 5. (a) Ultraviolet-visible (UV-VIS) spectra of Ag nanoparticles; and (b) an example of X-ray fluorescence spectrometry (XRF) spectrum of the nanocomposite SiC/Ag/CE/SDS. A: Absorbance.

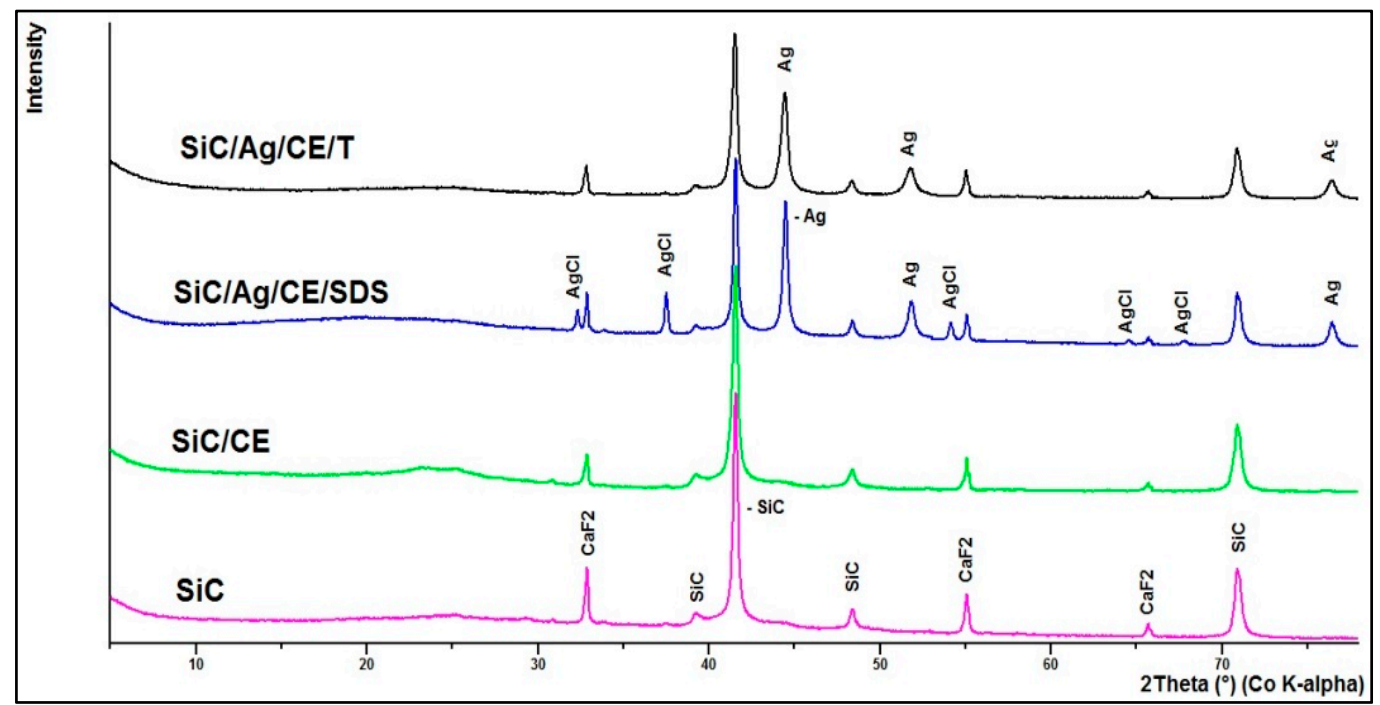

Figure 6. X-ray powder diffraction (XRD) of investigated materials.

\subsection{Respirometric Analysis}

For many nanoparticles, the minimum inhibitory concentration (MIC) is usually measured as a primary indication of bactericidal properties. This determination can be performed by evaluation of the optical density in microbial cultures, or on microtiter plates with a growth indicator $[18,25]$. This approach may be unreliable for the presented nanocomposites. SiC nanofibers form quite heterogeneous mixtures in an aqueous suspension, which makes it difficult to conduct a series dilution of the test material. Therefore, it was decided to evaluate the bactericidal properties based on respirometric curves, which determine the $\mathrm{CO}_{2}$ production in small batch cultures, with the addition of the studied nanomaterials (Figures 7 and 8). In addition, the curves allowed for a better comparison of the bacterial response to the presence of toxic substances. Based on the respirometric analysis, $\mathrm{SiC}$ nanofibers and the SiC/CE nanocomposite did not significantly inhibit microbial growth in the range $0.2-2 \mathrm{mg} \cdot \mathrm{mL}^{-1}$ (curves not shown; their course was very similar to the control). However, for $\mathrm{SiC} / \mathrm{Ag} / \mathrm{CE} / \mathrm{SDS}$ and $\mathrm{SiC} / \mathrm{Ag} / \mathrm{CE} / \mathrm{T}$, there were significant differences in the rate of $\mathrm{CO}_{2}$ production. 
For E. coli, the MICs for $\mathrm{SiC} / \mathrm{Ag} / \mathrm{CE} / \mathrm{SDS}$ and $\mathrm{SiC} / \mathrm{Ag} / \mathrm{CE} / \mathrm{T}$ were $2 \mathrm{mg} \cdot \mathrm{mL}^{-1}$ and slightly above $2 \mathrm{mg} \cdot \mathrm{mL}^{-1}$, respectively. MIC values for B. cereus were similar, but it appeared that B. cereus had a higher sensitivity to $\mathrm{SiC} / \mathrm{Ag} / \mathrm{CE} / \mathrm{SDS}$ and a lower sensitivity for $\mathrm{SiC} / \mathrm{Ag} / \mathrm{CE} / \mathrm{T}$ relative to E. coli.

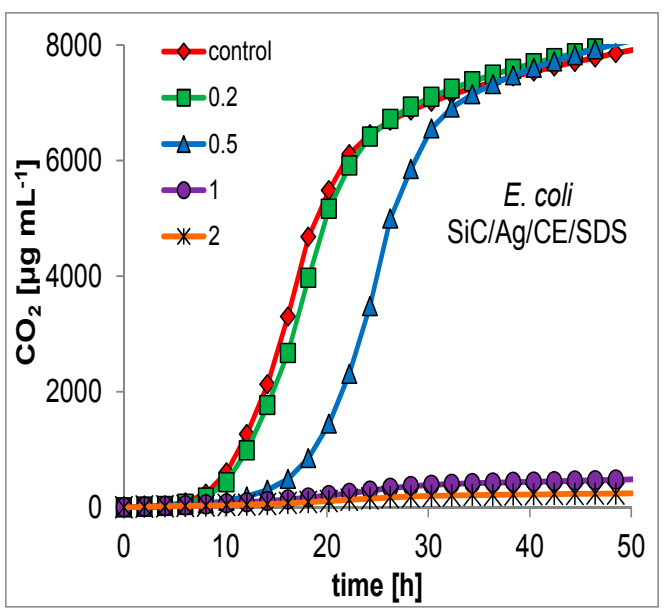

(a)

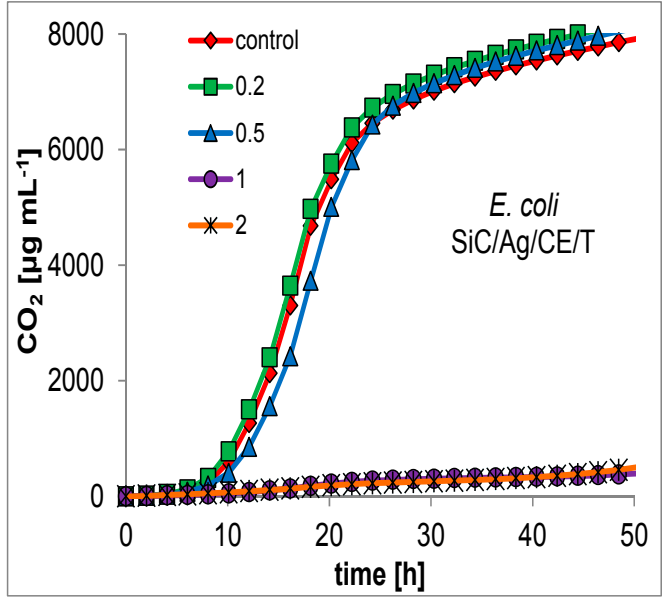

(b)

Figure 7. Respirometric curves showing the growth of E. coli at different concentrations $\left(\mathrm{mg} \cdot \mathrm{mL}^{-1}\right.$; as shown in the insets) of (a) $\mathrm{SiC} / \mathrm{Ag} / \mathrm{CE} / \mathrm{SDS}$; (b) $\mathrm{SiC} / \mathrm{Ag} / \mathrm{CE} / \mathrm{T}$.

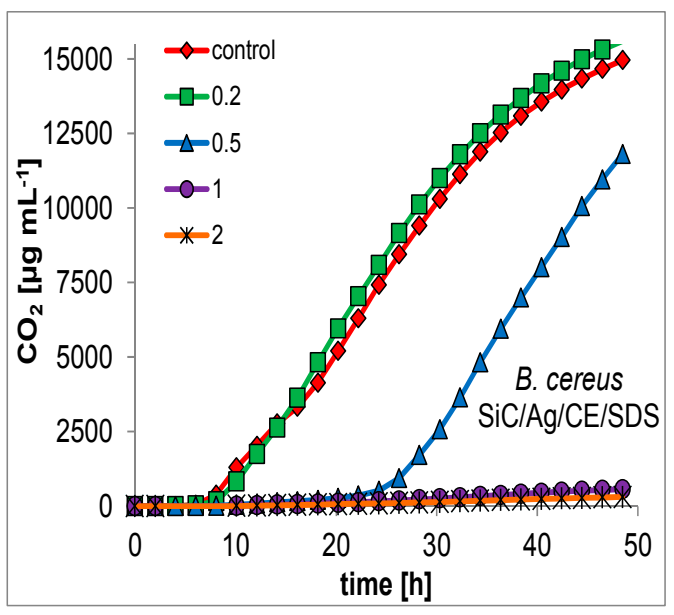

(a)

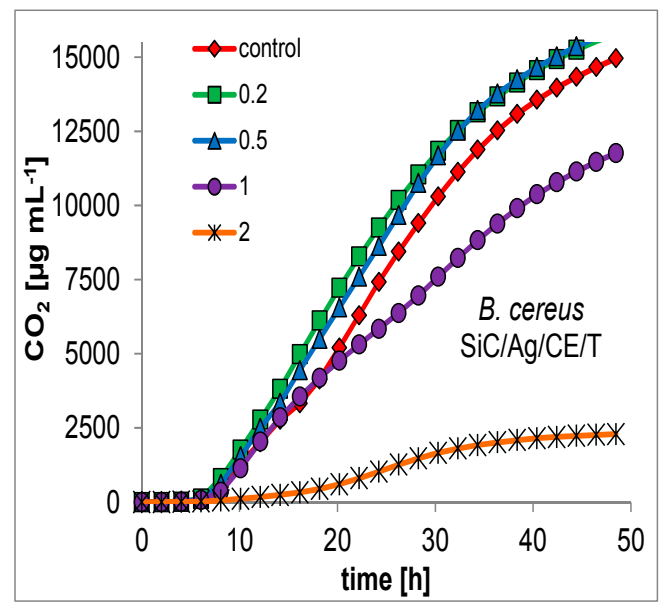

(b)

Figure 8. Examples of respirometric curves of growth of B. cereus at different concentration (legend, $\mathrm{mg} \cdot \mathrm{mL}^{-1}$ ) of nanocomposites. (a) $\mathrm{SiC} / \mathrm{Ag} / \mathrm{CE} / \mathrm{SDS}$; (b) $\mathrm{SiC} / \mathrm{Ag} / \mathrm{CE} / \mathrm{T}$.

\subsection{Catalase and Dehydrogenase Activities}

Many studies indicate that the two most important factors that affect nanostructured material toxicity are mechanical injury of the cell membrane integrity, and reactive oxygen species (ROS) generation and oxidative stress. The loss of cell membrane integrity and ROS generation may also lead to lipid peroxidation [26,27]. In this study, we measured the impact of SiC/Ag nanocomposites on microbial growth and $\mathrm{CO}_{2}$ production. Significant catalase and dehydrogenase activities were observed in treated cultures (Figure 9a). Catalase activity is responsible for the decomposition of hydrogen peroxide, which can be generated in cells as a result of dismutation of the superoxide radical $\left(\mathrm{O}_{2}{ }^{-}\right)$ catalyzed by superoxide dismutase. It can be assumed, therefore, that the presence of ROS may lead to increased activity of an important enzyme that protects against ROS. A significant increase in catalase activity was observed in Escherichia coli cultures in the presence of $\mathrm{SiC} / \mathrm{Ag} / \mathrm{CE} / \mathrm{SDS}$ and $\mathrm{SiC} / \mathrm{Ag} / \mathrm{CE} / \mathrm{T}$ 
nanocomposites. For Bacillus cereus, growth was observed in all cultures with nanomaterials except for $\mathrm{SiC} / \mathrm{Ag} / \mathrm{CE} / \mathrm{SDS}$. This was probably because of insufficient bacterial growth within a given time, and an apparent reduction in enzymatic activity was observed. This experiment indicated the greater sensitivity of B. cereus to $\mathrm{SiC} / \mathrm{Ag} / \mathrm{CE} / \mathrm{SDS}$ compared to the other nanomaterials. Chowdhuri et al. [4] showed a similar decrease in catalase activity in cultures of E. coli and Staphylococcus aureus in the presence of a nanocomposite based on graphene, chitosan, and $\mathrm{ZnO}$ nanoparticles. However, it can be assumed that, in this case, results were also affected by inadequate microbial growth. The increase in catalase activity was also demonstrated in cultures with $\mathrm{SiC} / \mathrm{CE}$, particularly for $\mathrm{B}$. cereus. It is possible that $\mathrm{CE}$ increased the adhesion of negatively charged bacterial cells onto $\mathrm{SiC} / \mathrm{CE}$ aggregates formed in an aqueous suspension. A similar effect was observed by Chowdhuri et al. [4] for graphene oxide and a chitosan nanocomposite.

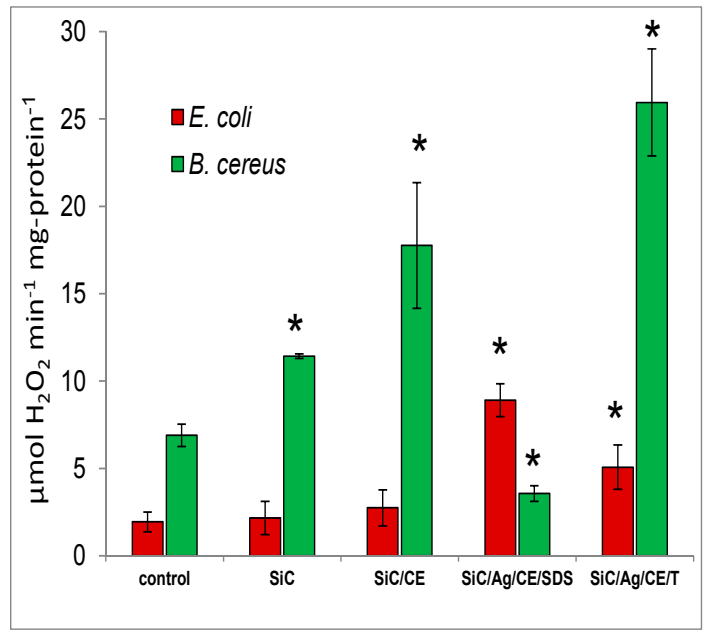

(a)

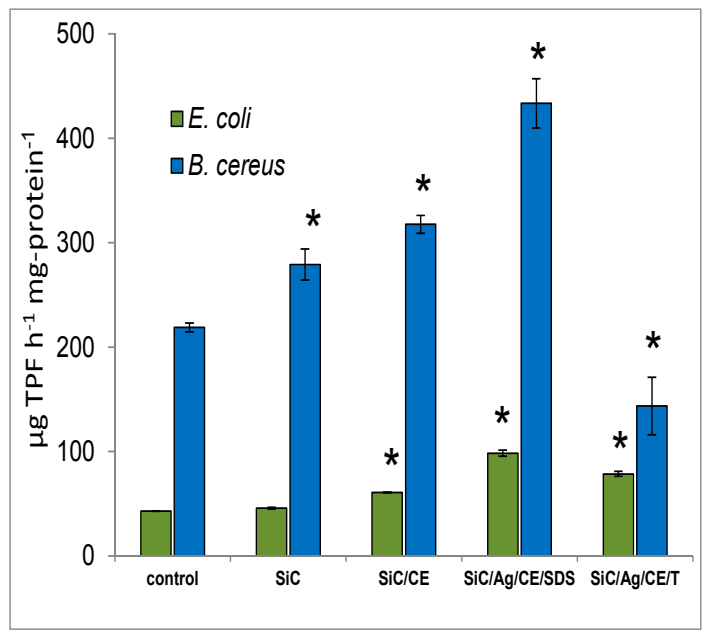

(b)

Figure 9. (a) Catalase activity and (b) dehydrogenase activity after treatment of E. coli or B. cereus with $\mathrm{SiC}$ nanofibers and nanocomposites at a concentration of $1 \mathrm{mg} \cdot \mathrm{mL}^{-1}$. Significant differences $\left(^{*}\right)$ compared to controls and the standard deviation are also indicated.

The dehydrogenase activity in the same treated cultures is presented in Figure $9 \mathrm{~b}$. The activity increased for $E$. coli in the presence of $\mathrm{SiC} / \mathrm{CE}, \mathrm{SiC} / \mathrm{Ag} / \mathrm{CE} / \mathrm{SDS}$, and $\mathrm{SiC} / \mathrm{Ag} / \mathrm{CE} / \mathrm{T}$. The greatest activity was found for $E$. coli and B. cereus in cultures with $\mathrm{SiC} / \mathrm{Ag} / \mathrm{CE} / \mathrm{SDS}$. Surprisingly, however, the dehydrogenase activity in $B$. cereus cultures with $\mathrm{SiC} / \mathrm{Ag} / \mathrm{CE} / \mathrm{T}$ decreased. It seems that, similar to the case of catalase, the observed effect may be brought about by differences in the growth kinetics or other factors that are not obvious. The addition of tetrazolium substrates to the cell culture leads to their reduction, and the formation of a colored formazan, mainly because of dehydrogenase activity. However, under certain conditions, these substrates may also be reduced, incidentally, as a result of free radical reactions with the superoxide radical [28]. Regardless of the main reaction responsible for the reduction of tetrazolium substrates, it can be assumed that the measured dehydrogenase activity is a reflection of the physiological state of the cells. Dehydrogenase activity, oxidative stress, ROS generation, and processes leading to the uncoupling of phosphorylation and energy dissipation take place in these cells.

\subsection{Viability Test}

One of the important effects of the bacteria-nanostructure interaction is the loss of cell membrane integrity [11,29], which may increase the permeation of dyes, such as propidium iodide (PI), into cells. In a normal physiological state, such dyes are removed from cells. Contact with the nanostructures may lead to mechanical damage, as was often demonstrated in the case of single- and multi-walled carbon 
nanotubes [11,30], or on $\mathrm{SiC}$ in the form of nanofibers and nanorods $[9,10]$. In this study, an interesting effect was noted. In $E$. coli cultures treated with $\mathrm{SiC}$ nanofibers, a loss of viability was observed, especially in bacteria adsorbed on the surface of the $\mathrm{SiC}$ nanofiber aggregates (Figure 10). This result is consistent with previously published data [9]. However, for $\mathrm{SiC} / \mathrm{CE}$, this effect disappeared, and the viability was similar to that of the control. The CE in the SiC/CE most likely reduced the mechanical interactions between bacterial cells and $\mathrm{SiC}$ nanofibers. A loss of cell viability was also observed in bacteria treated using nanocomposites with silver. However, this effect may be caused, more by the properties of AgNPs, than by injury to cell membranes caused by SiC. This hypothesis can be confirmed by results from cultures of $B$. cereus. The loss of viability was significantly greater than the control only for $\mathrm{SiC} / \mathrm{Ag} / \mathrm{CE} / \mathrm{SDS}$ and $\mathrm{SiC} / \mathrm{Ag} / \mathrm{CE} / \mathrm{T}$. This effect was not observed in the other cases, probably because of the structure of the Gram-positive bacterial cell wall [31].

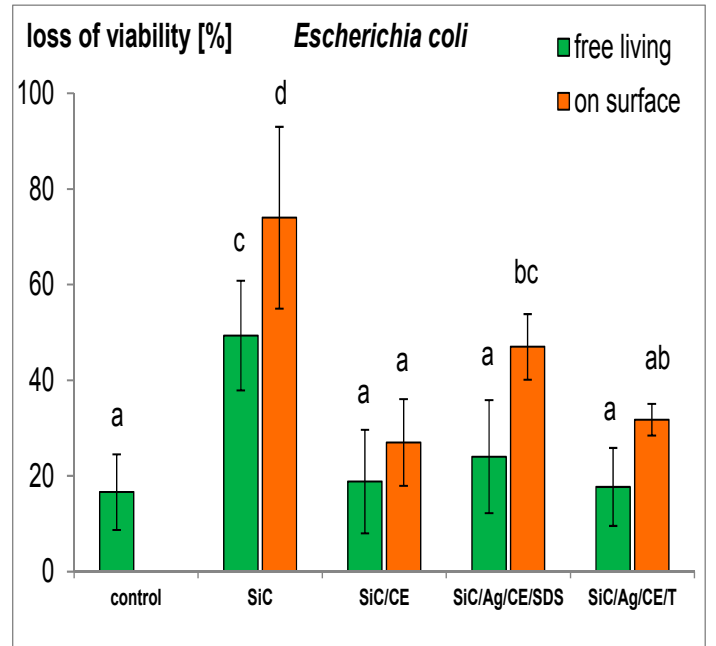

(a)

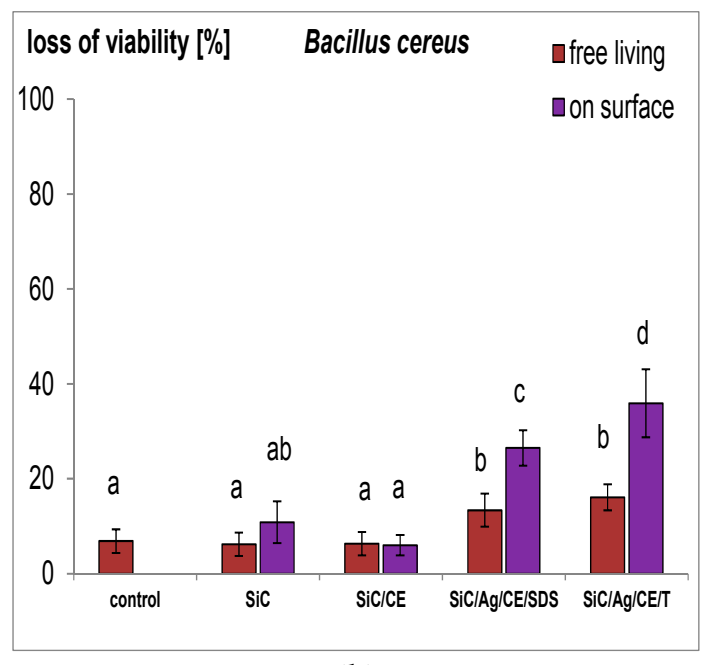

(b)

Figure 10. Loss of viability (\%) of free-living cells and those adsorbed onto the surface of aggregates of nanofibers SiC and nanocomposites. (a) Escherichia coli; and (b) Bacillus cereus. The same letters indicate that the values do not differ significantly at $p<0.05$. The error bars indicate the standard deviation.

\section{Materials and Methods}

\subsection{Synthesis of SiC Nanofibers}

$\mathrm{SiC}$ was prepared by combustion [6]. The combustion mixture was prepared by dry mixing calcium disilicide $\left(\mathrm{CaSi}_{2}\right)$ and poly (tetrafluoroethene) powders in a ceramic mortar. After pressing the powders into a cylindrical pellet, $5 \mathrm{~g}$ of sample were placed in a graphite crucible in a stainless steel autoclave $(350 \mathrm{~mL})$, which was subsequently filled with helium at an initial pressure of 1.0 MPa. Combustion was initiated with an electrically-heated resistance wire (0.1-mm diameter). Spongy combustion products were removed from the autoclave with water. The suspension was filtered, and the gray deposit obtained was purified in a three-step process: heating in $98 \% \mathrm{H}_{2} \mathrm{SO}_{4}$, calcination in air $\left(700^{\circ} \mathrm{C}\right)$, and heating in $25 \% \mathrm{NaOH}$, and washing with plenty of water. Nanomaterials were characterized using X-ray powder diffraction (XRD), Raman spectroscopy, elemental analysis, scanning electron microscopy (SEM), and transmission electron microscopy [5]. The SiC nanofibers were covered with a thin layer of silica.

\subsection{Synthesis of SiC/CE Nanocomposites}

$\mathrm{SiC}$ nanofibers $(100 \mathrm{mg})$ were placed in a flask $(50 \mathrm{~mL})$ and $20 \mathrm{~mL}$ of deionized water was added. The mixture was mixed on a magnetic stirrer $(1000 \mathrm{rpm})$ for $2 \mathrm{~min}$ at $25^{\circ} \mathrm{C}$. With continuous stirring, $2 \mathrm{~mL}$ of $\mathrm{HCl}$ (diluted in water 1:1) was added and $2 \mathrm{~mL}$ of a saturated solution of $\mathrm{CE}\left(\approx 0.4 \mathrm{~g} \cdot 100 \mathrm{~mL}^{-1}\right)$ 
in Schweizer's reagent (synthesized in laboratory from $\mathrm{Cu}(\mathrm{OH})_{2}$ and ammonia) was added in small portions. If required, $\mathrm{HCl}$ was added to adjust the $\mathrm{pH}$ to $\sim 7$. The obtained suspension was centrifuged $(0.5 \mathrm{~min}, 1000 \times \mathrm{g})$ and washed in deionized water. The resulting product was placed on a filter, washed with water three times, and then freeze dried for $12 \mathrm{~h}$.

\subsection{Synthesis of $\mathrm{SiC} / \mathrm{Ag} / \mathrm{CE}$ Nanocomposites}

The nanocomposite was synthesized in two different reaction mediums. In one case, a solution of sodium dodecyl sulfate (SDS) was used (Sigma-Aldrich, Sigma-Aldrich Sp. z.o.o, Poznan, Poland) to form a SiC/Ag/CE/SDS composite. In the second case, Tween 20 (Chemsolve, WITKO Sp. z.o.o, Łódź, Poland) was used to obtain a SiC/Ag/CE/T nanocomposite. To the flask (50 mL), $100 \mathrm{mg}$ of SiC nanofibers and $20 \mathrm{~mL}$ of an aqueous solution of SDS (1\%) or Tween $20(1 \%)$ were added. The mixture was stirred on a magnetic stirrer $(1000 \mathrm{rpm})$ for $2 \mathrm{~min}$ at $25^{\circ} \mathrm{C}$. Then, with continuous stirring, $200 \mu \mathrm{L}$ of solution of $\mathrm{AgNO}_{3}(0.5 \mathrm{M})$ and $100 \mu \mathrm{L}$ of aqueous solution of hydrazine $(80 \%$, Avantor Performance Materials, Gliwice, Poland) were added. Hydrazine solution was added dropwise in portions. The mixture was left for $\sim 5 \mathrm{~min}$ with continuous stirring, followed by the addition of $2 \mathrm{~mL}$ $\mathrm{HCl}$ (diluted in water 1:1) and then $2 \mathrm{~mL}$ of a saturated solution of CE in Schweizer's reagent in small portions. If required, $\mathrm{HCl}$ was added again to adjust the $\mathrm{pH}$ to $\sim 7-8$ and $\mathrm{CE}$ solution addition was continued. The obtained nanocomposite suspension was centrifuged $(0.5 \mathrm{~min}, 1000 \times g)$ and washed in deionized water. This was repeated at least five times to remove SDS or Tween 20. Next, the product was placed on a filter, washed with water three times, and then freeze dried for $12 \mathrm{~h}$. The hydrazine was chosen as a reducing agent to avoid side products and impurities, which are introduced into the final nanomaterial when other compounds, such as borohydrides, organic aluminum hydrides or phosphites, are used.

\subsection{Synthesis of AgNPs}

AgNPs were synthesized to evaluate the influence of reaction conditions on nanoparticle size. $200 \mu \mathrm{L} \mathrm{AgNO}_{3}(0.5 \mathrm{M})$ was added to the $20 \mathrm{~mL}$ of SDS solution (1\%) or Tween 20 solution (1\%). Next, $100 \mu \mathrm{L}$ hydrazine $(80 \%)$ was added in small portions. The synthesis conditions were the same as those described above (magnetic stirrer, temperature), but the suspension did not contain SiC nanofibers. Then, $\mathrm{HCl}$ and ammonia solutions (25\%, instead of a CE solution) were added in the same proportion with a pH control, as described above. Next, the obtained AgNPs (AgNP/SDS and AgNP/T) were washed and centrifuged twice $(2 \mathrm{~min}, 15,000 \times g)$ and suspended in deionized water.

\subsection{Composites Properties}

The SiC nanofibers, nanocomposites, and AgNPs were examined using SEM without coating (Sigma VP, Carl Zeiss Microscopy GmbH, Oberkochen, Germany). To evaluate the distribution of AgNPs in the nanocomposites, energy-dispersive X-ray spectroscopy (Bruker, Berlin, Germany) mapping was conducted. X-ray fluorescence (XRF) analysis of the water suspension of SiC nanofibers and nanocomposites was used to determine the AgNP content of the nanocomposites. This analysis was conducted on an XRF spectrometer (Panalytical MiniPal 4, Almelo, The Netherlands) at $20 \mathrm{kV}$, $200 \mu \mathrm{A}$ and with an Al-filter for $60 \mathrm{~s}$. The aqueous suspension of AgNPs was used as a standard. XRD spectra of SiC nanofibers and nanocomposites were measured (Panalytical $X^{\prime}$ Pert PRO MPD, Almelo, The Netherlands, $\mathrm{Cu} \mathrm{K} \alpha$ radiation) for $2 \theta$ from $10^{\circ}$ to $95^{\circ}$. The ultraviolet-visible (UV-VIS) spectra of AgNPs were obtained with a UV-VIS spectrophotometer (Genesys 10S UV-VIS, Thermo Fisher Scientific, Madison, WI, USA).

\subsection{Microorganisms and Media}

Escherichia coli (ATCC 8739) and Bacillus cereus (ATCC 11778) strains were obtained from our collection of isolated microorganisms (Geomicrobiology Laboratory, Faculty of Geology, University of Warsaw, Warsaw, Poland). The taxonomic affiliation was confirmed by sequencing 
analysis of the $16 \mathrm{~S}$ rDNA gene. The bacteria were cultivated in liquid and solid tryptic soy broth (TSB, Sigma-Aldrich, Sigma-Aldrich Sp. z.o.o, Poznań, Poland) comprised of the following $\left(\mathrm{g} \cdot \mathrm{L}^{-1}\right)$ : casein peptone, 17; soya peptone, 3; glucose, 2.5; $\mathrm{NaCl}, 5 ; \mathrm{K}_{2} \mathrm{HPO}_{4}, 2.5$ and agar (as solid medium), 20. The final $\mathrm{pH}$ was 7.3 . The media were autoclaved at $121^{\circ} \mathrm{C}$ for $15 \mathrm{~min}$.

\subsection{Measurement of $\mathrm{CO}_{2}$ in Cultures with Nanocomposites}

Respirometry analyses of microbial cultures with different amounts of nanocomposites were implemented to estimate the minimum inhibitory concentration (MIC). A MicroOxymax (Columbus Instruments, Columbus, $\mathrm{OH}, \mathrm{USA}$ ) respirometer was used to measure the amount of $\mathrm{CO}_{2}$ formed by the microbial activity of $E$. coli and B. cereus. The $\mathrm{CO}_{2}$ sensor range was $0 \%-15 \%$ volume. The test was conducted as follows. Ten milliliters of sterile medium (TSB) and $0.2,0.5,1$, and $2 \mathrm{mg} \cdot \mathrm{mL}^{-1}$ of investigated materials were placed in a 100-mL sterile glass bottle (Simax, Alchem Sp. z.o.o, Warsaw, Poland). Then, $0.5 \mathrm{~mL}$ of bacteria suspension (approximately $10^{8}$ colony-forming units (cfu) $\mathrm{mL}^{-1}$ in $0.9 \% \mathrm{NaCl}$ ) was added and the bottle was connected to a respirometric system. The cultures were stirred (120 rpm) at $25{ }^{\circ} \mathrm{C}$ for $48 \mathrm{~h}$. The amount of $\mathrm{CO}_{2}$ produced was measured automatically every $2 \mathrm{~h}$. The tests were repeated twice. Control experiments were conducted under the same conditions without nanostructures.

\subsection{Measurement of Dehydrogenases Activity}

Dehydrogenases activities in cultures after treatment with $\mathrm{SiC}$ nanofibers and nanocomposites were determined in triplicate using triphenyltetrazolium chloride (TTC). TTC can be used by microorganisms as an electron acceptor, and the production of insoluble formazan from TTC reflects dehydrogenases activity [32]. Ten milliliters of TSB medium was mixed with $10 \mathrm{mg}$ (ca. $0.5 \mathrm{MIC}$ ) of investigated nanomaterials in a 100-mL sterile glass bottle (Simax). Next, $1 \mathrm{~mL}$ of inoculum was added (approximately $10^{8} \mathrm{cfu} / \mathrm{mL}$ in $0.9 \% \mathrm{NaCl}$ ) and the obtained suspension was stirred for $6 \mathrm{~h}(120 \mathrm{rpm}$ ) at $25^{\circ} \mathrm{C}$. Then, $5 \mathrm{~mL}$ of the suspension was added to a test tube. Subsequently, $1 \mathrm{~mL}$ of $3 \%$ TTC and $50 \mathrm{mg}$ of $\mathrm{CaCO}_{3}$ were added $\left(\mathrm{CaCO}_{3}\right.$ was added to maintain a neutral $\left.\mathrm{pH}\right)$. The test tube was sealed using parafilm and incubated for $1 \mathrm{~h}$ at $30{ }^{\circ} \mathrm{C}$ in darkness. After incubation, $0.5 \mathrm{~mL}$ of $37 \%$ formaldehyde was added and the suspension was filtered through a $0.45-\mu \mathrm{m}$ filter (Merck-Millipore, Merck Sp. z.o.o, Warsaw, Poland). Formazan retained on the filter was extracted with $96 \%$ ethanol and the solution color was determined by spectrophotometry (Genesys UV-VIS, Thermo Fisher Scientific, Madison, WI, USA). Dehydrogenases activity was measured as the amount of TTC reduced to formazan per hour in relation to the protein content $\left(\mu \mathrm{g} \cdot \mathrm{h}^{-1} \cdot \mathrm{mg}\right.$-protein $\left.{ }^{-1}\right)$. The control was a culture incubated without nanostructures. To assess whether the investigated materials can interfere with measurements of dehydrogenases activity, an abiotic control was conducted. This test was performed under the same conditions described above, using a sterile medium without bacteria.

\subsection{Catalase Activity}

Catalase activity was conducted in the same cultures described above with dehydrogenase activity according to Luck [33]. Approximately $100 \mu \mathrm{L}$ of culture was added to the reaction volume of $3 \mathrm{~mL}$ containing PBS buffer ( $\mathrm{pH} 7.0$ ) and $10 \mathrm{mM} \mathrm{H}_{2} \mathrm{O}_{2}$. The rate of change of absorbance at $240 \mathrm{~nm}$ was recorded $\left(\mathrm{dA} \cdot \mathrm{min}^{-1}\right)$. Catalase activity was calculated by using the molar extinction coefficient of $43.6 \mathrm{~L}^{-1} \cdot \mathrm{M}^{-1} \cdot \mathrm{cm}^{-1}$. The enzyme activity was expressed as $\mu \mathrm{mol} \mathrm{H}_{2} \mathrm{O}_{2}$ consumed $\mathrm{min}^{-1} \cdot \mathrm{mg}_{\text {-protein }}{ }^{-1}$. In additional experiments, the interference with $\mathrm{SiC}$ nanofibers and nanocomposites under the same conditions, but without bacteria, was evaluated.

\subsection{Viability Test}

The viability test was performed according to Szala and Borkowski [9]. Briefly, to analyze the loss of viability, solutions of propidium iodide (PI) $\left(2 \mathrm{mg}, 0.1 \mathrm{~L}^{-1}, \mathrm{pH} 7.4\right)$ and acridine orange (AO) (5 mg $0.1 \mathrm{~L}^{-1}, \mathrm{pH} 7.4$ ) were prepared in phosphate buffer. Four milliliters of sterile saline solution 
$(0.9 \% \mathrm{NaCl})$ and $5 \mathrm{mg}$ of the investigated nanomaterials were added (ca. $0.5 \mathrm{MIC})$ to a 20-mL glass bottle. Subsequently, $1 \mathrm{~mL}$ of E. coli or B. cereus suspension (approximately $10^{8} \mathrm{cfu} \mathrm{mL}^{-1}$ in $0.9 \%$ $\mathrm{NaCl})$ was added to the mixture and mixed for $120 \mathrm{~min}$ at $25^{\circ} \mathrm{C}(200 \mathrm{rpm})$. Then, the suspension was mixed with sucrose $(60 \%)$ to separate unadsorbed bacteria. After centrifugation ( $2 \mathrm{~min}, 2600 \times g)$, the residue and unadsorbed bacteria in the supernatant were stained as follows. An amount of $0.2 \mathrm{~mL}$ of the supernatant or residuum and $30 \mu \mathrm{L}$ of PI were added to a test tube and left for $10 \mathrm{~min}$ in darkness. Later, $15 \mu \mathrm{L}$ of $\mathrm{AO}$ was added (staining for $2 \mathrm{~min}$ ) to the test tube. After staining, $10 \mu \mathrm{L}$ of the suspension was placed in a microscopic glass slide and covered with a coverslip. Next, ten representative fluorescence images of cells adsorbed onto the nanocomposite aggregate surface were acquired using an epifluorescence microscope with a B-filter. Results from the microscopic analysis were expressed as a ratio of the number of cells stained with PI (red-orange) divided by the number of cells stained with PI plus cells stained with AO (green).

\subsection{Protein Measurements}

To analyze the number of bacteria without using the cultivation method, the correlation between bacterial protein content and optical density $($ at $\lambda=600 \mathrm{~nm}$ ) was plotted for $E$. coli and B. cereus separately. Protein measurement was conducted according to the Lowry method with some modifications [34].

\subsection{Statistical Analysis}

The obtained data (viability test) were analyzed for significant mean differences using a one-way analysis of variance (ANOVA) at $p<0.05$. Post hoc tests for pair-wise differences and the identification of homogeneous subgroups were conducted using Tukey's honestly significant difference procedure. Homogenous subgroups are indicated by diagrams marked with the same lowercase letters. ANOVA was computed with Statistica 10 software (StatSoft. Inc., Tulsa, OK, USA).

\section{Conclusions}

$\mathrm{SiC}$ nanofibers can function as good carriers for silver nanoparticles. Such nanocomposites, together with CE as a stabilizer, may be materials with useful antibacterial properties. The tested nanocomposites showed antibacterial activity, probably because of the generation of oxidative stress in cells. Mechanical damage to membrane integrity appeared to be less important. Nanocomposites that contained Ag exhibited stronger bactericidal effects than the $\mathrm{SiC}$ nanofibers. The addition of $\mathrm{CE}$ reduced the effects of mechanical damage and can potentially increase the adsorption of negatively charged bacterial cells to the nanocomposite aggregate in an aqueous suspension. However, this hypothesis should be confirmed in future experiments. The obtained nanocomposites may have practical application in air- and water-purifying systems. Active filters based on $\mathrm{SiC}$ nanofibers and AgNPs may have strong bactericidal properties, and, thus, may not have the disadvantages of typical filters that are based on activated carbon.

Acknowledgments: This study was partially supported by the European Union within European Regional Development Fund, (POIG.02.02.00-00-025/09).

Author Contributions: Andrzej Borkowski conceived and designed the experiments; Andrzej Borkowski and Tomasz Cłapa performed the experiments; Mateusz Szala synthesized nanofibers SiC; Arkadiusz Gasiński performed SEM analysis; Andrzej Borkowski and Marek Selwet wrote and edited the paper.

Conflicts of Interest: The authors declare no conflicts of interest.

\section{References}

1. Jaiswal, S.; Duffy, B.; Jaiswal, A.K.; Stobie, N.; McHale, P. Enhancement of the antibacterial properties of silver nanoparticles using $\beta$-cyclodextrin as a capping agent. Int. J. Antimicrob. Agents 2010, 36, $280-283$. [CrossRef] [PubMed] 
2. Akhavan, O.; Abdolahad, M.; Abdi, Y.; Mohajerzadeh, S. Silver nanoparticles within vertically aligned multi-wall carbon nanotubes with open tips for antibacterial purposes. J. Mater. Chem. 2011, 21, 387-393. [CrossRef]

3. Su, R.; Jin, Y.; Tong, M.; Kim, H. Bactericidal activity of Ag-doped multi-walled carbon nanotubes and the effects of extracellular polymeric substances and natural organic matter. Colloids Surf. B 2013, 104, 133-139. [CrossRef] [PubMed]

4. Chowdhuri, A.R.; Tripathy, S.; Chandra, S.; Roy, S.; Sahu, S.K. A ZnO decorated chitosan-graphene oxide nanocomposite shows significantly enhanced antimicrobial activity with ROS generation. RSC Adv. 2015, 5, 49420-49428. [CrossRef]

5. Huczko, A.; Bystrzejewski, M.; Lange, H.; Fabianowska, A.; Cudziło, S.; Panas, A.; Szala, M. Combustion synthesis as a novel method for production of 1-D SiC nanostructures. J. Phys. Chem. B. 2005, 109, 16244-16251. [CrossRef] [PubMed]

6. Cudziło, S.; Szala, M.; Huczko, A.; Bystrzejewski, M. Combustion reactions of poly (carbon monofluoride), $(\mathrm{CF})_{\mathrm{n}}$ with different reductants and characterization of products. Propellants Explos. Pyrotech. 2007, 32, 149-154. [CrossRef]

7. Barillet, S.; Simon-Deckers, A.; Herlin-Boime, N.; Mayne-L'Hermite, M.; Reynaud, C.; Cassio, D.; Gouget, B.; Carrière, $\mathrm{M}$. Toxicological consequences of $\mathrm{TiO}_{2}, \mathrm{SiC}$ nanoparticles and multi-walled carbon nanotubes exposure in several mammalian cell types: An in vitro study. J. Nanopart. Res. 2010, 12, 61-73. [CrossRef]

8. Pourchez, J.; Forest, V.; Boumahdi, N.; Boudard, D.; Tomatis, M.; Fubini, B.; Herlin-Boime, N.; Leconte, Y.; Guilhot, B.; Cottier, M.; et al. In vitro cellular responses to silicon carbide nanoparticles: impact of physic-chemical features on pro-inflamatory and pro-oxidative effects. J. Nanopart. Res. 2012, 14, 1143-1155. [CrossRef]

9. Szala, M.; Borkowski, A. Toxicity assessment of $\mathrm{SiC}$ nanofibers and nanorods against bacteria. Ecotoxicol. Environ. Saf. 2014, 100, 287-293. [CrossRef] [PubMed]

10. Borkowski, A.; Szala, M.; Kowalczyk, P.; Cłapa, T.; Narożna, D.; Selwet, M. Oxidative stress in bacteria (Pseudomonas putida) exposed to nanostructures of silicon carbide. Chemosphere 2015, 135, 233-239. [CrossRef] [PubMed]

11. Kang, S.; Pinault, M.; Pfefferle, L.D.; Elimelech, M.M. Single-walled carbon nanotubes exhibit strong antimicrobial activity. Langmuir 2004, 23, 8670-8673. [CrossRef] [PubMed]

12. Akhavan, O.; Ghaderi, E. Toxicity of graphene and graphene oxide nanowalls against bacteria. ACS Nano 2010, 4, 5731-5736. [CrossRef] [PubMed]

13. Sondi, I.; Salopek-Sondi, B. Silver nanoparticles as antimicrobial agent: A case study on E. coli as a model for Gram-negative bacteria. J. Colloid Interface Sci. 2004, 275, 177-182. [CrossRef] [PubMed]

14. Panáček, A.; Kvítek, L.; Prucek, R.; Kolář, M.; Večeřová, R.; Pizúrová, N.; Sharma, V.K.; Nevěčná, T.; Zbořil, R. Silver Colloid Nanoparticles: Synthesis, Characterization, and Their Antibacterial Activity. J. Phys. Chem. B 2006, 110, 16248-16253. [CrossRef] [PubMed]

15. Kim, J.S.; Kuk, E.; Yu, K.N.; Kim, J.-H.; Park, S.J.; Lee, H.J.; Kim, S.H.; Park, Y.K.; Park, Y.H.; Hwang, C.-Y.; et al. Antimicrobial effects of silver nanoparticles. Nanomed. Nanotechnol. Biol. Med. 2007, 3, 95-101. [CrossRef] [PubMed]

16. Rai, M.; Yadav, A.; Gade, A. Silver nanoparticles as a new generation of antimicrobials. Biotechnol. Adv. 2009, 27, 76-83. [CrossRef] [PubMed]

17. Sharma, V.K.; Yngard, R.A.; Lin, Y. Silver nanoparticles: Green synthesis and their antimicrobial activities. Adv. Colloid Interface Sci. 2009, 145, 83-96. [CrossRef] [PubMed]

18. Petrus, E.M.; Tinakumari, S.; Chai, L.C.; Ubong, A.; Tunung, R.; Elexson, N.; Chai, L.F.; Son, R. A study on the minimum inhibitory concentration and minimum bactericidal concentration of Nano Colloidal Silver on food-borne pathogen. Int. Food. Res. J. 2011, 18, 55-66.

19. Kittler, S.; Greulich, C.; Diendorf, J.; Köller, M.; Epple, M. Toxicity of silver nanoparticles increases during storage because of slow dissolution under release of silver ions. Chem. Mater. 2010, 22, 4548-4554. [CrossRef]

20. Kruk, T.; Szczepanowicz, K.; Stefańska, J.; Socha, R.P.; Warszyński, P. Synthesis and antimicrobial activity of monodisperse copper nanoparticles. Colloids Surf. B 2015, 128, 17-22. [CrossRef] [PubMed]

21. De Azeredo, H.M.C. Nanocomposites for food packaging applications. Food Res. Int. 2009, 42, 1240-1253. [CrossRef] 
22. De Moura, M.R.; Mattoso, L.H.C.; Zucolotto, V. Development of cellulose-based bactericidal nanocomposites containing silver nanoparticles and their use as active food packaging. J. Food Eng. 2012, 109, 520-524. [CrossRef]

23. Dallas, P.; Sharma, V.K.; Zboril, R. Silver polymeric nanocomposites as advanced antimicrobial agents: Classification, synthetic paths, applications, and perspectives. Adv. Colloid Interface Sci. 2011, 166, 119-135. [CrossRef] [PubMed]

24. Maneerung, T.; Tokura, S.; Rujiravanit, R. Impregnation of silver nanoparticles into bacterial cellulose for antimicrobial wound dressing. Carbohydr. Polym. 2008, 72, 43-51. [CrossRef]

25. Krishnamoorthy, K.; Manivannan, G.; Kim, S.J.; Jeyasubramanian, K.; Premanathan, M. Antibacterial activity of $\mathrm{MgO}$ nanoparticles based on lipid peroxidation by oxygen vacancy. J. Nanopart. Res. 2012, 14. [CrossRef]

26. Sayes, C.M.; Gobin, A.M.; Ausman, K.D.; Mendez, J.; West, J.L.; Colvin, V.L. Nano-C 60 cytotoxicity is due to lipid peroxidation. Biomaterials 2005, 26, 7587-7595. [CrossRef] [PubMed]

27. Premanathan, M.; Karthikeyan, K.; Jeyasubramanian, K.; Manivannan, G. Selective toxicity of ZnO nanoparticles toward Gram-positive bacteria and cancer cells by apoptosis through lipid peroxidation. Nanomed. Nanotechnol. Biol. Med. 2011, 7, 184-192. [CrossRef] [PubMed]

28. Berridge, M.V.; Herst, P.M.; Tan, A.S. Tetrazolium dyes as tools in cell biology: New insights into their cellular reduction. Biotechnol. Annu. Rev. 2005, 11, 127-152. [PubMed]

29. Liu, S.; Zeng, T.H.; Hofmann, M.; Burcombe, E.; Wei, J.; Jiang, R.; Kong, J.; Chen, Y. Antibacterial activity of graphite, graphite oxide, graphene oxide, and reduced graphene oxide: Membrane and oxidative stress. ACS Nano 2011, 5, 6971-6980. [CrossRef] [PubMed]

30. Kang, S.; Herzberg, M.; Rodrigues, D.F.; Elimelech, M. Antibacterial effects of carbon nanotubes: Size does matter! Langmuir 2008, 24, 6409-6413. [CrossRef] [PubMed]

31. Borkowski, A.; Owczarek, F.; Szala, M.; Selwet, M. Interaction of Gram-positive and Gram-negative bacteria with ceramic nanomaterials obtained by combustion synthesis-Adsorption and cytotoxicity studies. Pol. J. Microbiol. 2016, 1, 161-170. [CrossRef]

32. Tarafdar, J.C. 2,3,5-triphenyltetrazolium chloride (TTC) as electron acceptor of culturable soil bacteria, fungi and actinomycetes. Biol. Fertil. Soils 2003, 38, 186-189.

33. Luck, H. Catalase. In Methods of Enzymatic Analysis; Bergmeyer, H.U., Ed.; Academic Press: New York, NY, USA, 1963; Section 3; pp. 885-894.

34. Borkowski, A.; Szala, M.; Cłapa, T. Adsorption studies of the Gram-negative bacteria onto nanostructured silicon carbide. Appl. Biochem. Biotechnol. 2015, 175, 1448-1459. [CrossRef] [PubMed] 